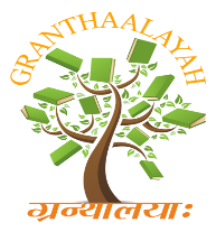

INTERNATIONAL JOURNAL OF RESEARCH GRANTHAALAYAH A knowledge Repository

\title{
ENVIRONMENTAL POLICIES AND MANAGEMENT IN INDIA
}

\author{
Gomti Chelani
}

Govt. Maharani Laxmibai Girls P.G. College Indore

\begin{abstract}
In this Universe the Earth is the only planet where life is possible. Modernization and industrialization affect nature in 2 ways. Firstly it is extremely destructive of environment in its search for inexpensive biomass-based raw materials and for the opportunities for waste disposal. Secondly modernization is transforming the very character of nature. The tendency is to reduce the diversity in nature and transform it in to high yielding monocultures.

India is country with a high level of population density. In the name of economic development often any human activity, which results in the destruction of an ecological space or in its transformation, is justified. Environmental issues were completely overlooked during the first 2 decades of economic development. Government realized the need for environmental protection in early 1970s. Environmental protection was adopted as directive principles of state policy in our Constitution. The protection of environment is also a fundamental duty of every citizen of India. Presently there are about 30 major enactments related to protection of environment being administered by the Central and State Governments. The problems concerning the policies of Government related to environmental protection and the implementation of various laws are discussed in this paper.

India's biggest challenge today is to identify and implement development process that will lead to greater equity, growth and sustainability. To achieve these goals Government policies should be reformed and it is our duty to come forward and make these policies successful.
\end{abstract}

\section{Keywords:}

Environment, protection, sustainability, policy.

\section{INTRODUCTION}

"The world's population, which is soon going to be close to ten billion with India's share full one billion on just $2 \%$ of world's space, administrators are faced with no small challenge. Our world is embarked on a precarious adventure that will test the Earth's elasticity of carrying capacity." 1 These lines written by Lamont C. Hempel in his book Environmental Governance in 1996 compel us to understand the gravity of the problem of environmental governance.

Modernization and industrialization affect nature in two ways. Firstly it is extremely destructive of the environment in its search for inexpensive biomass-based raw materials and for the opportunities for waste disposal. In the absence of strong laws, which are equally strongly implemented, there is no internalization of environmental costs and both public sector units and private industrialists prefer to pass them on to society. 
Secondly modernization is steadily transforming the very character of nature. In physical terms the tendency is to reduce the diversity in nature and transform it in to high yielding monocultures. The driving force for this transformation arises out of commoditization of nature. Maximum product and maximum profit is the aim. The effect of massive environmental change taking place in India has been disastrous for the people.

India is a poor country with a high level of population density. There is no ecological space left in the physical environment today which is not occupied by one human group or another for its sustenance. However, the biological diversity of the country is so rich that it may play a very important and crucial role in future for the survival of entire mankind, if it is conserved with utmost care. But in the name of economic development often any human activity which results in the destruction of an ecological space or in its transformation, is justified. ${ }^{2}$

Environmental issues were completely overlooked during the first 2 decades (1950 to 70) of economic development. It was in early 1970s that government realized the need for environmental protection as an integral part of industrial policy. Unfortunately considerable damage had already been done to India's natural resources by the time preventive measures were taken. Thus land/soil degradation has taken place due to floods, water logging, salination, indiscriminate mining, and faulty agricultural practices. Similarly forest wealth is dwindling due to withdrawal of forest products (timber, fuel and wood), overgrazing, forest fires and location of development projects in forest areas. Further more noise levels in urban areas of India are excessively high due to the rise in population, automobiles and industrial activities. Complete reversal of this damage is unlikely; therefore efforts need to focus on preserving global biological resources before they are damaged.

\section{GOVERNMENT POLICIES AND INITIATIVES}

Part 4 of the Constitution of India contains directive principles of state policy. Article 48 A of the Constitution falling under part 4 states that "The state shall endeavor to protect and improve the environment and to safeguard the forests and wild life of the country." ${ }^{3}$ Similarly the part 4A of the Constitution inserted by the constitution $42^{\text {nd }}$ amendment act 1976 contains fundamental duties of every citizen of India. Article 51 A G of the Constitution states "It shall be the duty of every citizen of India to protect and improve the natural environment including forests, lakes, rivers and wild life and to have compassion for living creatures." 4

Problems related to environment received direct attention of the government in $4^{\text {th }}$ five year plan 1969-74 and a committee was set up in 1972 to look these at problems and suggest solutions. Another committee was set up in January 1980 for reviewing the existing legislative measures and administrative machinery for ensuring environmental protection. Following the recommendations of this committee the Department of Environment was set up in 1980 which was upgraded to a full-fledged Ministry of Environment and Forests in 1985. Presently there are about 30 major enactments related to protection of environment being administered by the central and state governments. The prominent among these are the following - The Wildlife Protection Act 1972, The Water (Prevention and Control of Pollution) Act 1974, The Forest Conservation Act 1980, The Air (Prevention and Control of Pollution) Act 1981, The Environment Protection Act 1976, The Motor Vehicle Act 1938 (as amended in 1988), The Public Liability Insurance Act 1991. 5

\section{IMPLEMENTATION OF THE LAWS}

The implementation of these laws is not satisfactory. Expressing dissatisfaction with the implementation of environmental schemes and laws, the tenth five year plan observed the major 
instruments with the states to check environmental degradation is undoubtedly regulations. The country has adopted almost all environmental protection acts and rules enforced in the developed countries but environmental degradation continues despite the existence of a long standing policy and legal cum institutional framework of environmental protection. The need for reducing the gap between principle and practice cannot be overemphasized. ${ }^{6}$

The plane document suggested inter alia the following 2 measures to check environmental degradation. Environmental clearance of projects by state pollution control boards takes a long time. There is a need for standardization of procedures and setting of time frames for control of industrial pollution limits on affluent discharge. Leading down an economic instrument can also be introduced to force the industry to move towards zero discharge. The industry should be made to pay higher penalty if its affluent discharge contains a higher level of pollutants.

In India Government has taken various measures, preventive as well as promotional, to improve environment. However, it has not used pollution taxes for environmental protection. Pollution taxes are levied in many countries with public support. Brazil, Columbia and Venezuela, charge a forestry tax when a tree harvesting is not compensated by equivalent reforestation. Landfill tax is imposed in many western countries including Britain.

The policy in India has focused on providing subsidies i.e. tax concessions to industries in various forms. These subsidies have not proved effective in controlling pollution. They do not force pollutants to adopt pollution abatement technology. Similarly there has been lack of an appropriate price policy for the use of natural resources. The approach paper to the ninth five year plan has lamented this fact as follows-

"The most important methodology for preventing undue depletion of natural resources is by ensuring their efficient use at all levels. This has 2 important dimensions. First exhaustible or vulnerable natural resources should be priced appropriately in order to prevent exploitation. In India since a large proportion of natural resources are subjected to administered price, there has been a tendency to underprice resources quite significantly. This approach needs to be changed urgently. Second technology which decreases the use of natural resources needs to be developed and promoted rigorously. ${ }^{7}$

Since independence 3 factors primarily have amplified the crisis of environmental governance. First the lack of adequate data to warn administrators of ecological limits. Second, precarious economic indicators that set priorities to guide the use of natural resources and lastly the politicians' preoccupation with the election cycle. This has shifted the burden of adjustment to those who are politically powerless as much as it does on future generations. The gradual erosion of ecological limits has swept of the home, hearth and the occupations of so many and so rapidly that the administration of the country is ill-prepared to resolve and act upon. ${ }^{8}$

India's biggest challenge today is to identify and implement development process that will lead to greater equity, growth and sustainability. The environment is not just pretty trees and tigers threatened plants and ecosystems. It is literally the entity on which we all subsist and on which the entire agricultural and industrial development depends. Development and protection of environment both are important for us. It is our responsibility to make a balance between them.

\section{REFERENCES}

1. Hampel, Lamont C. Environmental Governance Island Press U.S.A. 1996 P.11

2. Abhay Kumar Environmental Protection in India New Century Publication New Delhi 2005 p. 1

3. The Constitution of India as on $1^{\text {st }}$ September 1991 Government of India P.14 
4. Ibid P.15

5. Abhay Kumar opcit P.4

6. Government of India Planning commission $10^{\text {th }} 5$ year plan (2002-07) Vol.2 P.1075

7. Approach Paper to the $9^{\text {th }} 5$ year plan Government of India Planning Commission P.36

8. Dr. Amita Singh The Politics of Environmental Administration Gulgotia Publishing Co. New Delhi 2000 P.1 